\title{
タイ国、洪水低地帯における 地下水取水と地下水収支解析 ON GROUNDWATER BUDGET SIMULATION AND GROUND WATER EXTRACTION IN LOWLAND FLOODPLAIN, THAILAND
}

\author{
Phattaporn MEKPRUKSAWONG ${ }^{1}$ ・市川勉 ${ }^{2} \cdot$ 山田正 $^{3}$ \\ Phattaporn MEKPRUKSAWONG, Tsutomu ICHIKAWA and Tadashi YAMADA \\ 1 Member of JSCE, Royal Irrigation Department, Thailand (Samsen Road, Dusit, Bangkok 10300, Thailand) \\ 2 正会員 工博 九州東海大学教授 工学部都市工学科（干862-8652 熊本県熊本市渡鹿9-1-1） \\ 3 正会員 工博 中央大学教授 理工学部土木工学科（テ112-8551 東京都文京区春日1-13-27）
}

\begin{abstract}
The floodplain in Phichit province, Thailand always has flood in rainy season and water lacking in dry season. This area is a major recharge area of Thailand and farmers set many wells for drawing groundwater, because of insufficient surface water during two times of paddy crop and unavailable irrigation systems. This causes severe decreasing of groundwater level with no sign of recovery. In inundation area, the average flood depth is about $2 \mathrm{~m}$ and has duration 1-2 month. The authors set up the observation systems in this study area to monitor their daily change in groundwater level, river water level, and rainfall. Flood water in this area recharges shallow aquifer and continuously flows down to deep aquifers. This paper presents the simulation of groundwater budget in this area based on the Tank model concept using data in 2002-2004. The results show that recharge through ground surface by flood is about $55 \%$ of annual recharge and $73 \%$ of annual recharge flow down to deeper aquifer.
\end{abstract}

Key Words: groundwater, flood plain, pumping, recharge, tank model

\section{1. はじめに}

タイ国には洪水が頻発する地域に農地が集中し ている.特に, Phichit県Yom川両岸に位置する農地は 毎年のように洪水が発生している.他方, この地域に は灌溉用水がないために, 地下水が主水源となり, 農 業用水として乾期のみならず雨期にも地下水が利用 されている.しかし, 特別な涵養機構もないため地下 水位は年々減少しつつあるが1), 2), この地域で地下水 の連続観測は行われていない. 浅い部分にある地下 水は地表面に近接しており（地表面下2-20m），それ ゆえに,地表面からの涵養が盛んである.タイ国王立 灌溉局 (RID： Royal Irrigation Department, Thailand) ᄂ 著者らはこの地域の地下水循環の解析を行うため, 降雨, 河川水位, 地下水位観測井戸を設置し, 観測を 行った.さらに、農業用の灌溉井戸の位置, 取水状況 のデータをアンケート及び聞き取り調査によって収 集した. 本研究ではこれらのデー夕を使って地下水 の取水量, 地下水の涵養量などの水収支解析を行っ たものである.この水収支解析には平面二次元の地
下水解析用に提案されたThiessen Polygon 型林括”

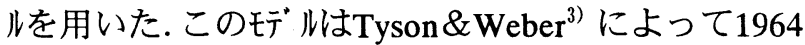
年に提案されたもので, 均質な地表付近の地下水に 関して, 連続式とDarcyの法則に基づいた運動方程式 に基礎をおいている.

\section{2. 研究地域}

研究地域は図-1に示したようにタイ国首都 Bangkokの北, 約 $350 \mathrm{~km}$ に位置するChao Phraya川の支 川であるYom川西岸である。この地域は面積約 $120 \mathrm{~km}^{2}$, Yom川の洪水域で灌溉網はない地域であ る. その領域は洪水域上低い河岸段丘の 2 つに別れ ている. 西から東方向へ勾配1\%以下の湿地と自然の 堤防が地表面の一般的状況であり,これらが, $3 \%$ 以 下の河床勾配のYom川に沿って広がっている4).

洪水汇濫は毎年9月から10月にかけてYom川の越 流によって発生し, 研究地域の $50 \%$ 近くが 1 ～2 月 の間氾濫する.この地域の季節は,冬期 (10月中旬から 2月）,夏期（2月中旬か 55月）, 雨期（5月から10月） 


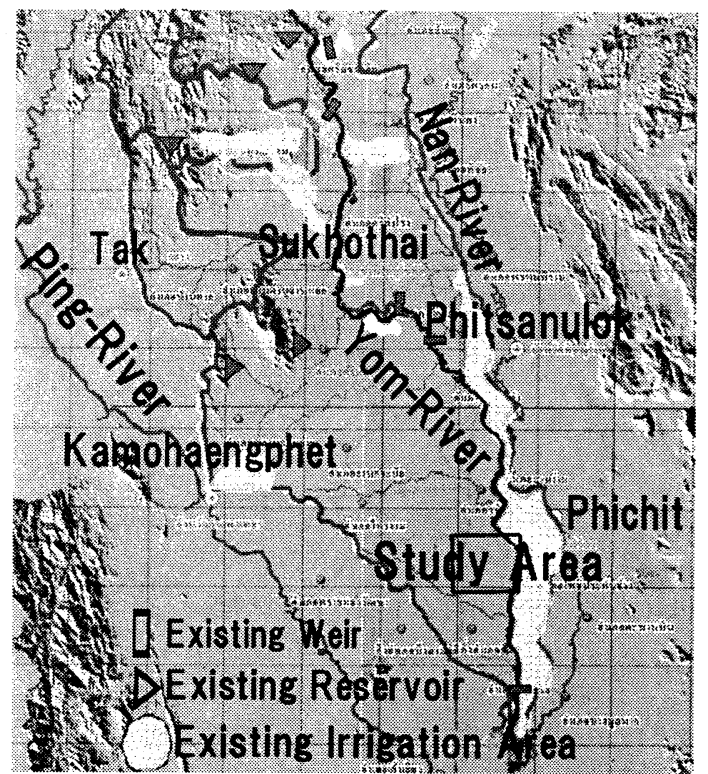

図-1 研究地域

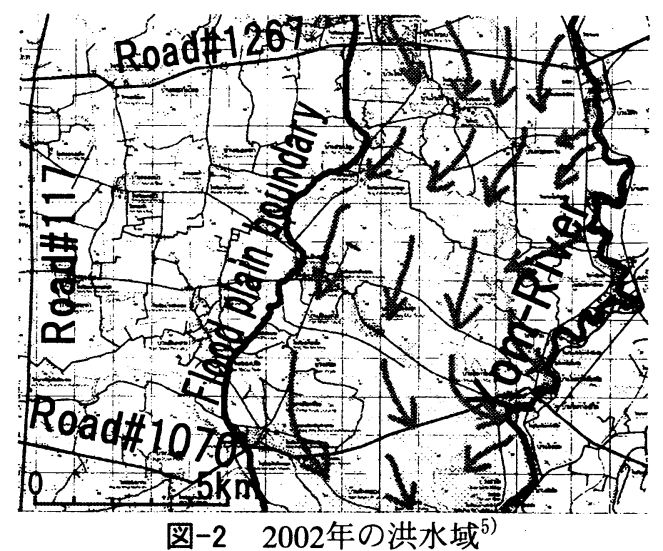

の3つに別れる.年降水量は $1434 \mathrm{~mm}$, 平均降雨日数は 80日であり,9月が最も降水量の多い月である.図-2は 2002年における洪水域を示した5).

この地域の地表面の水源はYom川, 細い水路, そして 農業用水池である. Yom川の流下能力は約 $360 \mathrm{~m}^{3} / \mathrm{s}$ で あり, 洪水期には流量がその流下能力を上回り標高 $34 \mathrm{~m}$ の堤防を越流する. 一方, この川は夏期の何ヶ月

（2月から3月にかけて）かは水が流れない期間があ る. 地下水は乾期の主水源であり, 図-3に示すように 約900の灌溉用井戸がある.図-3には土地利用も示し てあるが, この図に示しているように全体の $86 \%$ 水稲の二期作である.この水稲の作付けは洪水の状 況に左右され, Yom川の河川沿いでは9月から10月に かけて1〜2ケ月水稲作付けができなくなる. 洪水を 避けるために, 農家は4月末から5月に作付けし,8月 に刈り入れる.そして, 洪水が過ぎた 10 月下旬から 11 月にかけて次の作付けを行う. 洪水の無い地域では 1ケ月ほど遅れて作付けする. 台地部ではトウモ⿰コシ, 大 豆,忆托゙などが5\%の地域で栽培されている. 稲作 は主に二期作であるが、地表水と地下水の灌溉用水 の供給状況によって灌溉用水が不足する地域もあり， 地域によって98〜31\%の割合で二期作を行っている. 図-4は年間の農地での作付け状況を示している.

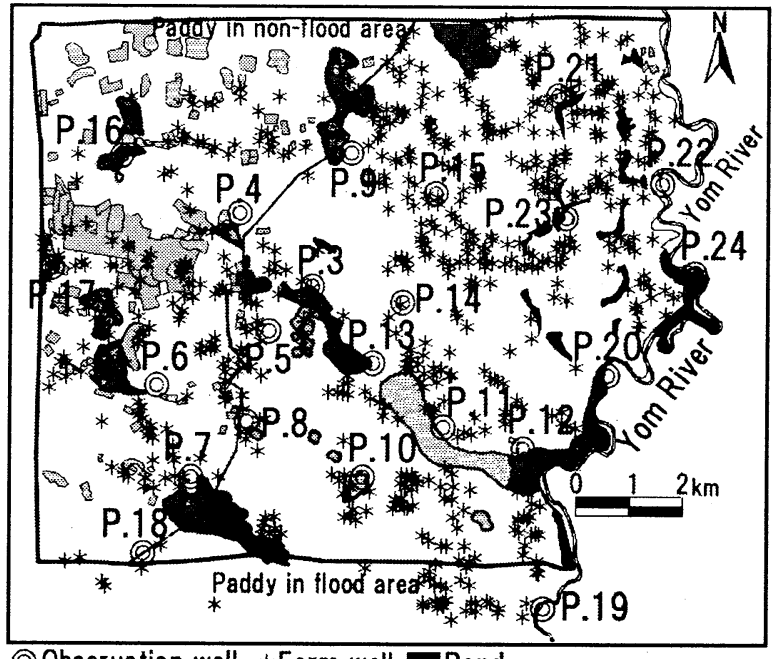

(O) Observation well *Farm well $D$ Pond

Land use Miscelleneous Orcharde Upland crop Village

図-3 土地利用, 観測井戸と灌溉用井戸

\begin{tabular}{|c|c|c|c|c|c|c|c|c|c|c|c|c|}
\hline crop & $\mathbf{J}$ & $\mathbf{F}$ & $\mathbf{M}$ & $\mathbf{A}$ & $\mathbf{M}$ & $\mathbf{J}$ & $\mathbf{J}$ & $\mathbf{A}$ & $\mathbf{S}$ & $\mathbf{O}$ & $\mathbf{N}$ & D \\
\hline $\begin{array}{c}\text { Paddy } \\
\text { (flood area) }\end{array}$ & & & & & & & & & & & & \\
\hline $\begin{array}{c}\text { Paddy } \\
\text { (non-flood are }\end{array}$ & & & $y$ & & & & & & & & & \\
\hline Upland crop & & & & 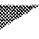 & 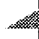 & & & & & & & \\
\hline
\end{tabular}

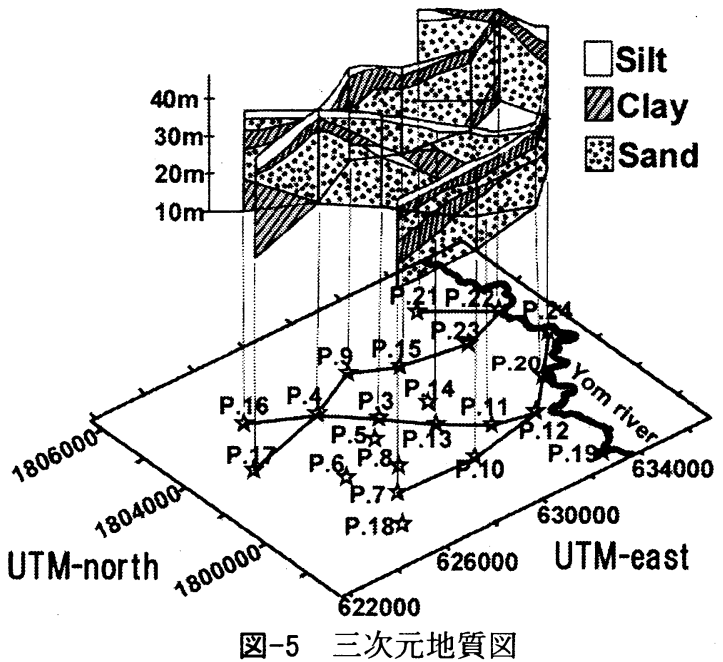

\section{3. 水理地質}

研究地域は長い間,Yom川の洪水による堆積の影 響を受けてきた. その結果, 複雑な地層が形成された. 地下水観測井掘削時のボーリングデータや現地揚水 試験, 土質試験などの結果を基に4つの地層堆積开仍 に分別し,地層図を作成した (図-5参照 $)^{6)}$.帯水層は 第二層と第三層に厚さ数 $\mathrm{m}$ で分布している.しかし, これら2つの帯水層を仕切る粘土層が研究地域の南 西部にしか存在せず,Yom川に近い地域では同一の 帯水層になっている.

著者らは2001年から22地点で地下水位, 1 地点で 河川水位そして1地点で降水量を測定している(図-3 


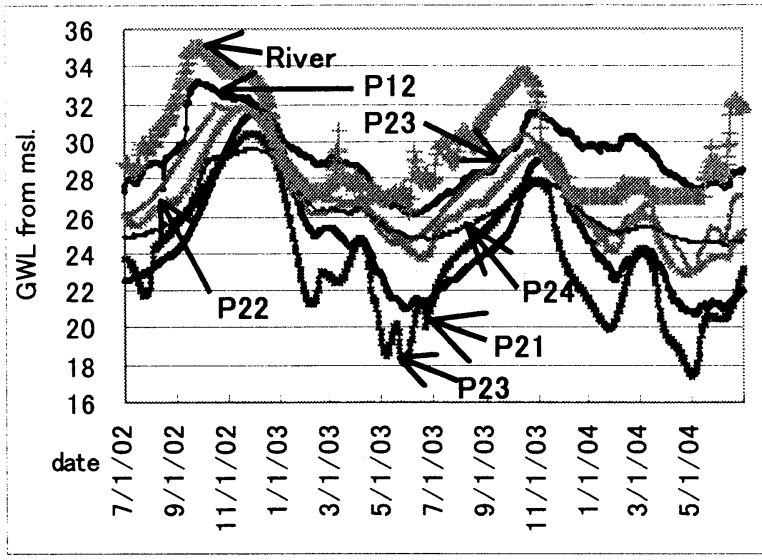

図一6 Yom川周辺の地下水位変動

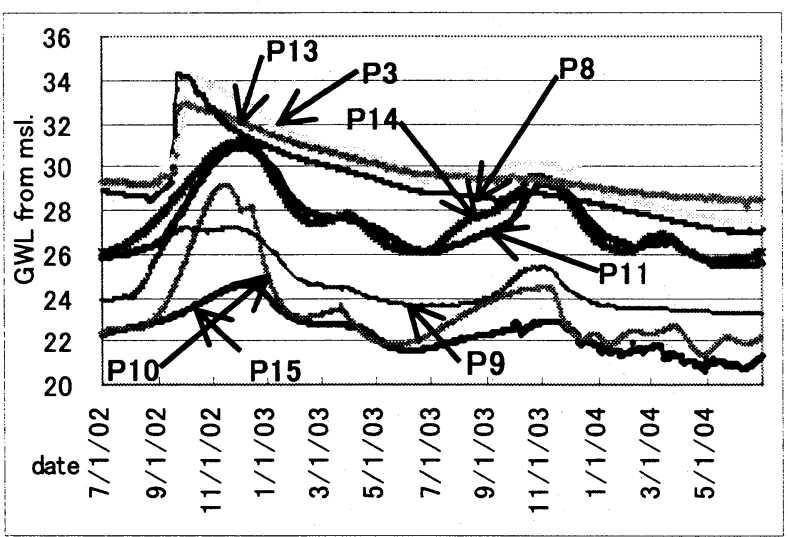

図-7 中央域の地下水位変動

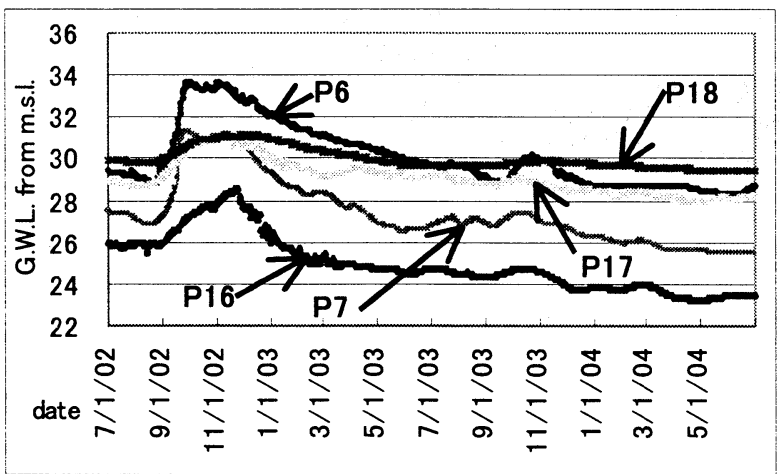

図-8 段丘域の地下水位変動

参照). 図-6〜8はこれらの観測網で観測した地下水 位と河川水位の 2002 年から2004年までの結果を示し た. 図-6はYom川の水位と河川に近い地点の地下水 位を示している.この地域の地下水は河川と直結し ており,汇濫地域のため河川の水位変動によく追随 している。図ー7は中央地域の地下水位変動であ る. 2002 年にはこの地域も洪水汇濫になったた め, Yom川の水位とよく似た変化をしているが, 氾濫 にならなかった2003年では地下水位の上昇はあまり 見られない.これらから洪水氾濫による地下水涵盖 があることがわかる.図-8は汇濫にならない西側丘 陵部の地下水位変動である.P6とP7は2002年には地 下水位が上昇している.P7は近くまで汇濫が来てい

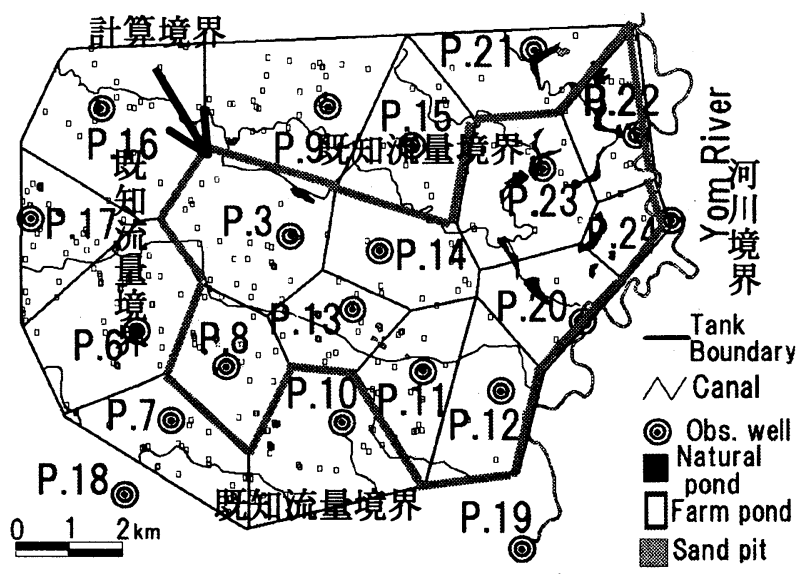

図-9 Thiessen Polygon と計算領域

た影響と思われる.P6は, 隣接した灌溉用の池の影 響と考えられ, 渴水年の 2003 年に地下水上昇はほと んど見られない.これらの地下水位と河川水位を用 いて地下水収支解析を行う。

\section{4. 水収支解析モデル}

\section{（1）基礎方程式と計算モテル}

研究地域は河川の汇濫地形であるため非常に平 坦で,かつ, 非常に広い範囲に帯水層が分布している. また, 地質的には帅・粘土層と砂・砂層の互層であ るが, 深さ $30 \mathrm{~m}$ 程度までに2つの帯水層があり,かつ これを分離している難透水層は研究地域の南西部に 存在するのみでほとんど一つの帯水層と考えても良 いと考えられる.しかし,地表からの涵養は農業など の土地利用, 氾濫, 河川など複雑な要因が多く,その ため, 地下水シシュレーションを行う前に, Tyson\&Weber に よるThiessen Polygon型のタンクモデルで水収支解析を 行った ${ }^{3)}$. 図-9はこの地域のThiessen Polygonによる 分割図である. 各要素の中心は観測井戸であり, おの おのの㚈の境界は観測井戸を結ぶ直線の垂直二等 分線で決められ, 図-9に示している.この研究地域の 地下水は汇濫原の地下水であるため, 周辺に明らか な境界として利用できるものは河川境界 (東側境界) だけである.その他の境界は地下水帯として連続し ている. そこで, 研究地域の外側に面した地点の各地 下水観測点は計算領域境界外の既知水頭測点として 取り扱い,その内側の访境界を通して流れる地下水 流量を計算し,既知流量境界とした. 計算領域は図-9 の太線内として解析を行った.

水収支式は式(1)で表される3).

$\nabla \bar{v}+S \frac{\partial h}{\partial t}+Q=0$

ここに, $\bar{v}$ はarcy流速, $h$ は各夘の中の地下水 位, $S$ は帯水層の有効空隙率, $Q$ は地表面の涵養,揚 水,下層への漏水など夕ンクへ流出入する流量であ る. Tyson\&Weberは式(1)を着目する夕夕夕 $j$ (図-9の計 算境界内の各夘)について式(2) のように変形した ${ }^{3)}$. 式 (2)で, $A_{j}$ は夕夕夕 $j$ の面積, $Y_{i, j}$ は夕夕夕 $i, j$ 間の通 


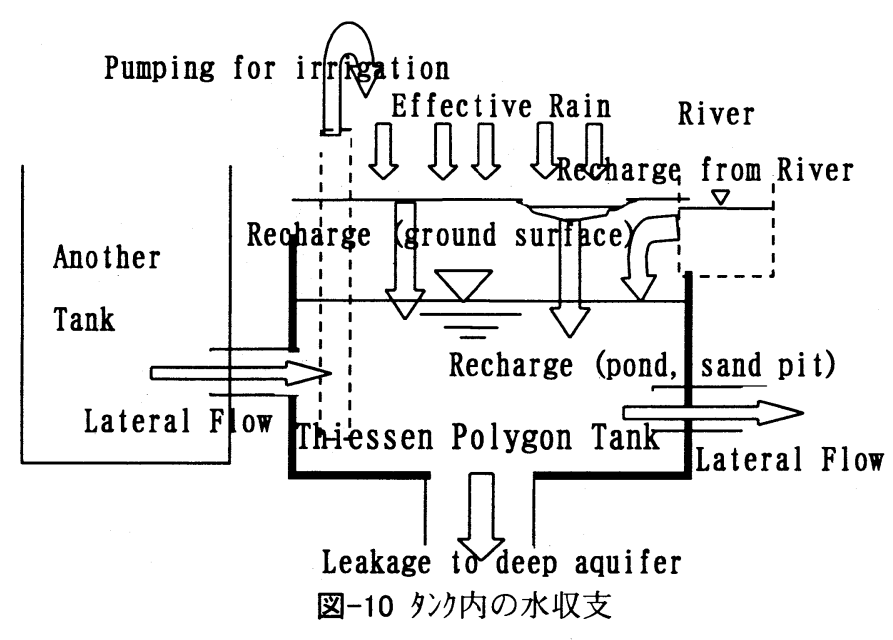

過伝導率， $J_{i, j}$ は夕ンク $i, j$ 間の地下水流動面 積, $L_{i, j}$ は夕夕夕 $i, j$ 間の距離, $k$ は透水係数, $i$ は着 目する夘 $j$ に隣接する多斿である.

$$
\begin{aligned}
& \Sigma_{i}\left(h_{i}-h_{j}\right) Y_{i, j}=A_{j} S_{j} \frac{d h_{j}}{d t}+A_{j} Q_{j}, \\
& Y_{i, j}=\frac{J_{i, j} k h_{i, j}}{L_{i, j}}
\end{aligned}
$$

式 (2)の左辺は地下水の側方流動量を, 右辺第一項は 各要素における $d t$ 時間当たりの貯留量の変化を表し, 第二項は各要素における鉛直方向の涵養・流出量を 表す.式(2)における涵養・流出として考えられるも のは図-10に示したような鉛直方向の流出入量, すな わち, 地表面からの降水, 水田, 洪水による涵養, 地下 水からの流出には灌溉用井戸からの揚水, 帯水層下 部を通じた漏水が考えられる. 側方の流れは各要素 間の地下水流動, 河川からの漏水が考えられる. 計算 期間は図-6〜8に示した研究地域全ての観測井戸で 連続デー夕を得ることのできた2002年7月〜2004年6 月の 2 年間とし, 時間ステップ $d t$ は 1 日とした.この期間 の河川水位 (標高), 降水量, 蒸発散量 $(E t 0)$ を図-11に 示す.この図から2002年9月12日〜24日は河川水位が 堤防の高さを越えていることがわかる.この氾濫は 12月初めまでこの地域に留まる. 2003年の河川水位 は堤防を越えていないが, 上流部からの水が河川に 近い範囲で汇濫を起こした.

\section{（2）涵養量·流出量の計算 \\ a) 渎養量}

地表面からの涵養は図-10に示したように降水, 水 田, 洪水, 灌溉用の池・砂採取場跡の池, 自然池などか らが考えられる.このうち, 各種の池からの涵養につ いては, 池の数, 面積, 池底の状況によって大きく変 化する.そのため, 定量的な評価ができない.した がって,これらの池からの涵養については, 地下水位 の変化と他の涵養の差から推定した.ただし,池の水 位が乾期には低下して涵養はほとんどないと考えら れる.また, 地下水位が洪水期に上限に達した状況で は涵養が促進できない状況になるので, 洪水期の地

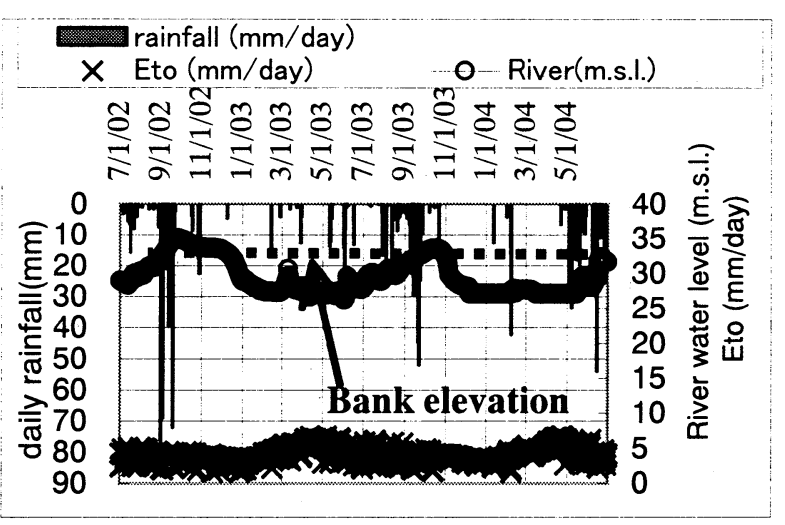

図-11 河川水位, 降水量と蒸発散量

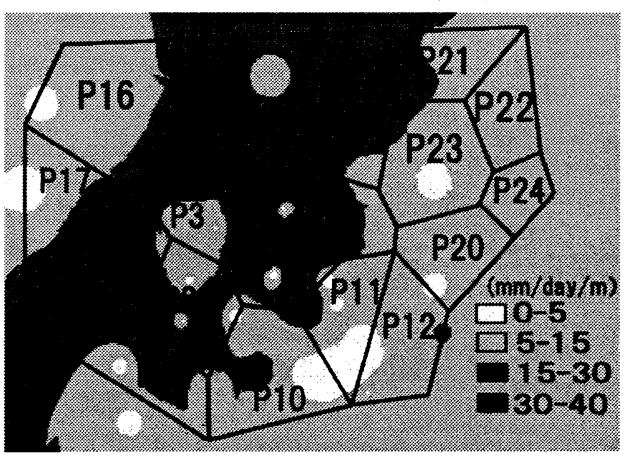

図-12 浸透能力係数 $a_{c}$ の分布

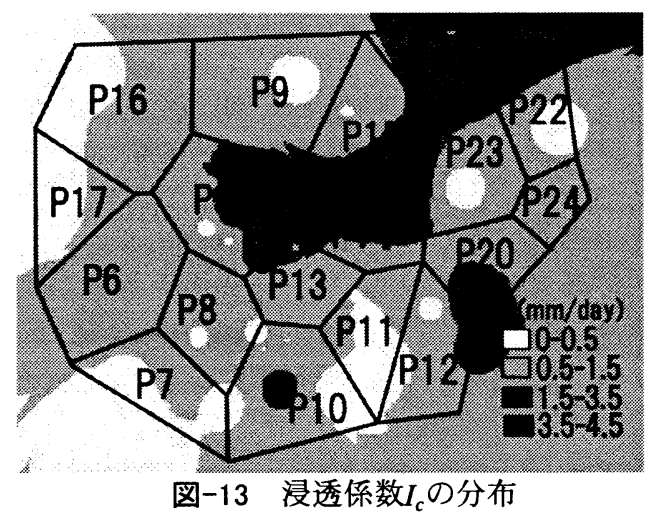

下水位のピ -ク時から乾期の終わる4月までは涵養は ないものとした. 次に, 地表面からの涵養は降水, 水 田及び洪水の湛水によるものである.これらの涵養 量は地表面の浸透能力に依存する.湛水する場合の 浸透については浸透能係数 $a_{c}(\mathrm{~mm} / \mathrm{day} / \mathrm{m}$, 単位湛水 深当たりの浸透高さ，図-12）を用い，降雨浸透に関し ては可能浸透係数 $I_{c}(\mathrm{~mm} / \mathrm{day}$, 図-13) を用いた.これ らの定数は現地試験によってその分布を求め, 各要 素の平均値を求め, 涵養量を計算した. 計算方法は, 降水の涵養量は, 降水が可能浸透量を超えた場 合, (要素の全面積) $\times$ (可能浸透量), 降水が可能浸 透量を超えない場合, (要素の全面積) $\times$ (降水量) で 計算した. 水田からの涵養量は, この地域の平均湛水 深 $(10 \mathrm{~cm}) \times$ (浸透能力係数) $\times$ (水田面積) から計算し た.しかし, 水稲作付け状況は地域によって変化する, 特に乾期では水不足が発生し作付けできない地域が あるので, 水稲作付け率(地域によって98〜31\%) を 


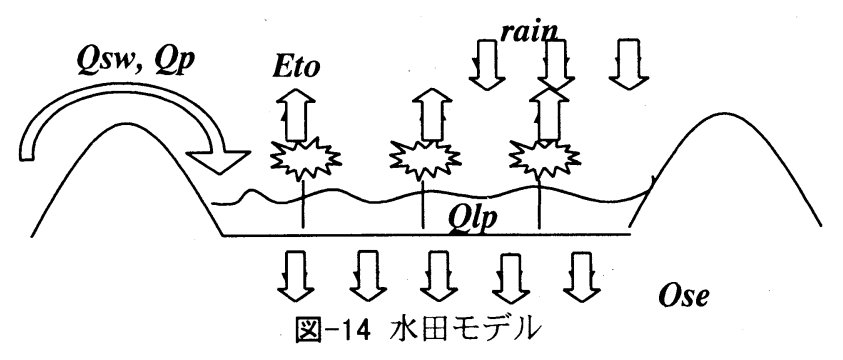

乗じることによって, 水田からの涵養量を決めた. 水稲作付け率は, 聞き取り調査, 資料収集によって決 めた. 洪水による涵養量は, 河川水位から洪水水深を 計算し, (洪水域の平均水深) $\times$ (洪水面積) $\times$ (浸透能 力係数 $) \times$ (水稲作付け率) から計算した.

\section{b）井戸からの揚水量}

井戸は灌溉網が無いこの地域の農業用水の主水 源である. 水稲作付け期間は図-3に示している. 地下 水揚水は水田への水の供給であるので, 水田の水収 支を考える. 図-14に示したように水田の水収支に関 係するものは, 降水( rain), 水田からの浸透 (Qse), 蒸 発散量 $(E t o)$,表流水の供給 $(Q s w)$ 及び地下水揚水 $(Q p)$ である.そこで, 各要素における表面水の水量, 浸透 能力, 蒸発散量を求めた. 表面水の水量はGISデー夕 と現地調査から面積, 平均水深を求め, 全水量を推定 した. 浸透能力は現地調査の結果（図-12）から各外 クの平均值を計算した. 蒸発散量は気象観測所及び RIDのデータを参照し, Penman-Montheithの式から求 めた ${ }^{7}$. また, 水田面積は土地利用図から求めた. 地 下水揚水量を計算する場合, 井戸からの揚水にかか るガ归代などの経済的理由から, 地表水を先に利用 する傾向にあり,その傾向を考慮して地下水揚水量 の日量を計算した. また, 約 900 本の井戸の深度を調 查し, 最上部の帯水層の底部より梁い井戸について は帯水層の深さに比例配分して, 対象とした帯水層 からの揚水量とした.

\section{c）地下水流動量と下部帯水層への漏水}

各壮間の地下水流動量は, 式 (2)の左辺の側方流 動項を計算した. 計算対象の夘とこれに接する各多 間の側方流動量の総和がその㚈の側方流動による $\mathrm{dt}$ 時間（1日）あたりの貯留量とし,この值から地下 水側方流動による地下水位変動量を求めた. この計 算で使う透水係数は現地揚水試験結果か ら, $\mathrm{k}=0.0032 \mathrm{~cm} / \mathrm{s}$, また, 有効空隙率は同様に $\mathrm{S}=0.083$ の值を用いた. Yom川の河川境界では, 河川 の側壁で大きな透水性があり, 河床部は固いシル・粘 土であった. そこで, 透水係数は帯水層と同じ值を用 い, 河川の帯水層との境界の面積を求め, Darcy則に よって水位勾配と流積から流量を計算した.

帯水層の上部からの漏水や帯水層間の漏水は, 一 般に, 式(3)で表すことができる.

$$
Q_{L}=-k_{z}^{\prime}\left(\frac{h-h_{L}}{b^{\prime}}\right) w l
$$

ここに, $Q_{L}$ は漏水量, $k^{\prime}{ }_{z}$ は鉛直方向の透水係数, $b^{\prime}$ は漏水層の層厚で, $k^{\prime}{ }_{z} / b^{\prime}$ は漏水係数である. また,

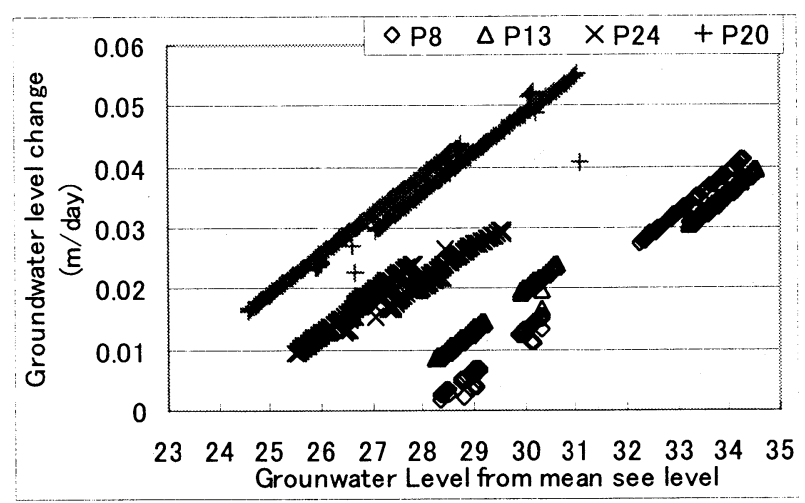

図-15 地下水位の日あたり低下量と地下水位

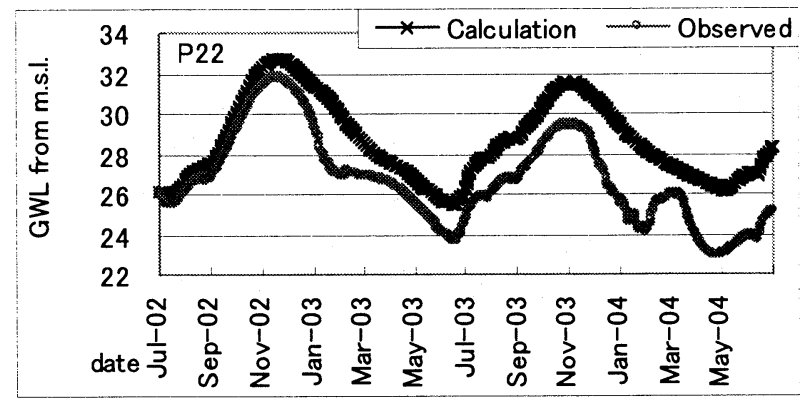

図-16 地下水位の変化比較 (Yom川沿い P20)

$w l$ は各多抄の面積である. $h, h_{L}$ は漏水のある上下 の帯水層または給水源の水頭である.この式(3) は, $\frac{Q_{L}}{w l}=F_{L}=-\frac{k_{z}^{\prime}}{b^{\prime}} h+\frac{k_{z}^{\prime}}{b^{\prime}} h_{L}$

と書き換えることが出来る.ここに， $F_{L}$ は, 漏水7ラック スである.もし,下部帯水層の水頭が大きな変化がな く一定と考えられるなら,この式(3)は直線の式に置 き換えられる.実際に, 下部の帯水層の水位変動は上 部の帯水層に比べ小さいことから, 漏水7ラックスを直線 式で表すことを試みた. 研究地域の地下水位変動は, 水位低下期は乾期であり, 水田の作付けがない場合, 地下水の流動のみが水位に影響を与える.そこで, 1 日あたりの地下水位低下量から側方流動による地下 水位変動量を引いた值を漏水7ラックスとし, 地下水位と の相関をとった. その例が, 図-15である. 図-15より, 漏水フラックスは式(4)の形式で表すことができると考え， 図-15の直線勾配が漏水係数として, この回帰式から 漏水フラックスを求めた。

\section{5. 計算結果}

前章で示した計算方法によって, 地下水の水収支 解析を行った. 図-16はYom川に沿った地域にある P20 の地下水位変動の比較である.この点では地下 水位の上昇過程はよく再現されているが, 低下過程 及び小規模な地下水位上昇は再現されていない. P20 は河川に近く河川と帯水層が直結しているところで あるので, 河川の水位変化の影響を受けやすいが, その形を追随できていない. 河川からの涵養につい てさらに検討する必要がある. 図-17は, 河川から 


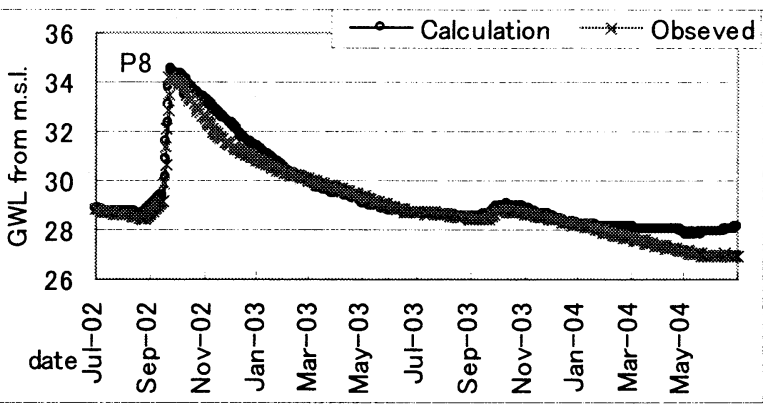

図-17 地下水位の変化比較(中央部 P8)

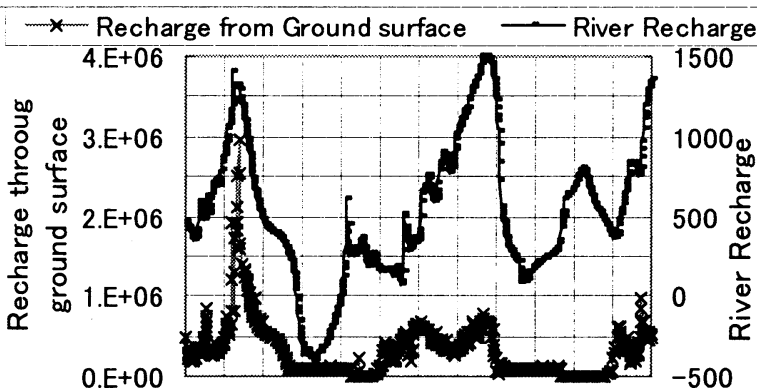

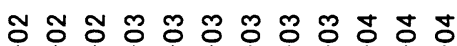

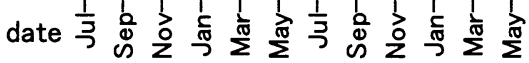

図-18 地表面からの涵養量と河川涵養量の日変化

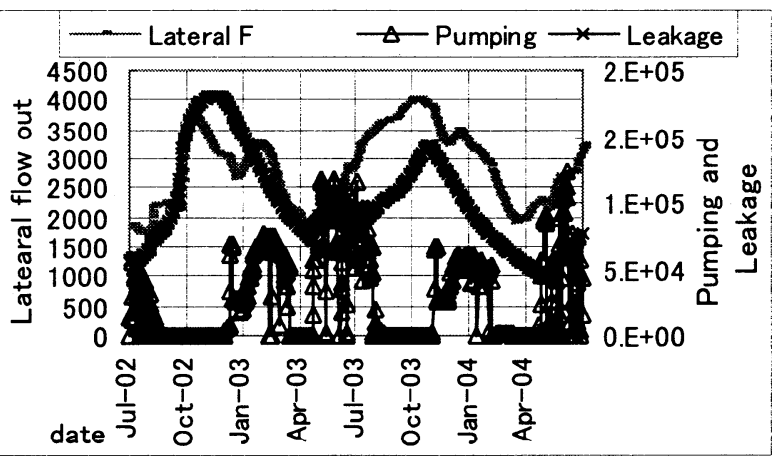

図-19 境界からの流出量, 揚水量と漏水量の日変化

$5 \mathrm{~km}$ 程度離れた洪水の縁部にあるP8の地下水位変動 の計算結果と観測値の比較である.この地点は, 河川 の影響を受けていないので, 複雑な地下水変動もな $<$, 計算結果もよく一致している.

この計算結果から地下水収支を求めた. 図-18は地 下水涵養に関する項目である地表面からの涵養と河 川の涵養を示している. 地表面の涵養は洪水期で日 最大約 300 万 $\mathrm{m}^{3}$ になり. 灌溉や雨期でも 100～200万 $\mathrm{m}^{3}$ の涵養があると推定された. 2002年7月から一年 間の総涵養量は約 5500 万 $\mathrm{m}^{3}$ であり, そのうち, 洪水 期 (約 3 ケ月) の涵養が約 $55 \%$ の 3100 万 $\mathrm{m}^{3}$ と洪水期の 地下水涵養が大きい.一方, 河川からの涵養量は日最 大 $1500 \mathrm{~m}^{3}$ 程度とあまり大きくないが, 河川沿いの地 域の地下水には複雑な影響を与えていると考えられ る.

次に, 流出である図-19を見ると, 計算領域外への 流出が日最大約 $4000 \mathrm{~m}^{3}$ とそれほど大きくないこと がわかる.流出で最も大きいのが漏水であり, 日最大
50 万 $\mathrm{m}^{3}, 2002$ 年 7 月から一年間で約 4000 万 $\mathrm{m}^{3}$ と全涵 養量の約73\%が下方へ涵養されている.この地域の最 上部の帯水層の地下水は, その地質構造の特殊性か ら. 水平方向の流動よりも鉛直方向の涵養が大きく, さらに深い帯水層の地下水の補給が迅速に行われて いることが推定される.また, 地下水は灌溉期を中心 に取水されており, 日量最大 15 万 $\mathrm{m}^{3}$ 程度と考えられ る. 2002 年 7 月からの 1 年間では約 1000 万 $\mathrm{m}^{3}$ もの地下 水が揚水されている.

\section{6. まとめ}

熱帯モンスーン地帯の低地洪水が頻発する水田地 域で地下水位、河川水位及び降水量の連続観測を行 い,Thiessen Polygon型の决㹸゙ルによって, 地下水収 支解析を行った結果,以下の結論を得た。

- 洪水の頻発するこの地域の地下水変動は洪水の涵 養を強く受け,洪水期の地下水涵養量は年間涵養量 約 5500 万 $\mathrm{m}^{3}$ の55\%に達する。

・河川からの漏水は最大 $1500 \mathrm{~m}^{3} /$ 日程度であるが,河 川周辺の地下水位変動には大きな影響を与えてい る.

- 地下水の揚水量は日最大 15 万 $\mathrm{m}^{3}$, 年間約 1000 万 $\mathrm{m}^{3}$ にのぼる.

・年間の漏水量は約 4000 万 $\mathrm{m}^{3}$ と推定され,最上部の帯 水層では水平方向の流れより,下部の地層への漏水 を主とする鉛直方向の流れが卓越している.

この地下水収支計算によって,ある程度の地下水 の状況が把握できた.今後このデータを用い,さらに 詳しい地下水シシュレ-ションをしていく予定である。

\section{参考文献}

1) Department of Local Administration: Thailand;The inventory of natural water resources in Thailand, pp. 219-222, 1988.

2) Public Works Department, Thailand: The feasibility study on groundwater conservation and recovery in Phichit province report, pp. 4-14, 1998.

3) Howell N. Tyson, Jr. and Ernst M. Weber: Groundwater management for the nation's future-computer simulation of groundwater basins, Journal of the HYDRAULIC DIVISION, Proceedings of the A.S.C.E., HY4, pp.59-76, July 1964.

4) Department of Mineral Resources, Thailand: Groundwater map manual, Phichit Province, pp.16-17, 2001.

5) Sombat Chuenchooklin, Tsutomu Ichikawa and Sa-nguan Patamatamkul: Flood flow pattern and distribution of infiltration over large floodplain and natural groundwater recharge area, Annual Journal of Hydraulic Engineering, JSCE, VOL.47, February, pp.211-216, 2003.

6) Phattaporn Mekpruksawong, Tsutomu Ichikawa and Tadashi Yamada: Hydrogeological condition and groundwater behavior in low land, Thailand, Journal of JSHWR, Vol.17, No.1, pp.32-42, 2004.

7) Royal Irrigation Department, Thailand: Crop coefficient of Penmans-Monteith, December, pp1-6, 1996. 